\title{
Identification of robust synthon in the molecular salts of 2-aminothiazole with substituted benzoic acids: A case study
}

\author{
MADHAVI ORUGANTI ${ }^{\mathrm{a}}$, RAGHAVAIAH PALLEPOGU ${ }^{\mathrm{b}}$ and DARSHAK R TRIVEDI ${ }^{\mathrm{a}, *}$ \\ ${ }^{a}$ Supramolecular Chemistry Laboratory, Department of Chemistry, National Institute of Technology \\ Karnataka (NITK), Surathkal, Mangalore 575 025, India \\ ${ }^{b}$ National Single Crystal Diffractometer Facility, University of Hyderabad, Hyderabad 500 046, India \\ e-mail: darshak_rtrivedi@yahoo.co.in
}

MS received 10 March 2014; revised 14 June 2014; accepted 01 July 2014

\begin{abstract}
Six new salts of an API intermediate 2-aminothiazole with different carboxylic acid coformers were synthesized and characterized by IR (Infrared spectroscopy), ${ }^{1} \mathrm{H}-\mathrm{NMR}$, DSC (Differential scanning calorimetry), XRPD (X-ray powder diffraction) and single crystal XRD. The crystal structure of the salts with benzoic acid, 2,3-, 2,4-, 2,5-, 2,6- dihydroxybenzoic acids and 2,4-dinitrobenzoic acid were determined. The thiazole moiety exhibited solvent (polarity) assisted tautomerism in all reported salts and proton transfer was noticed to the ring $\mathrm{N}$ of thiazole due to which two point supramolecular synthon $\mathrm{N}^{+}-\mathrm{H}$ (thiazole) $\cdots \mathrm{O}^{-}$(acid), $\mathrm{N}-\mathrm{H}$ (amine) $\cdots \mathrm{O}^{-}$(acid) was observed. The crystal structures were studied with respect to the positional effect of the competing functional groups like hydroxyl $(-\mathrm{OH})$ and nitro $\left(-\mathrm{NO}_{2}\right)$ as well as their donor and acceptor abilities for hydrogen bonding. The presence of the non-conventional hydrogen bond $(\mathrm{C}-\mathrm{H} \cdots \mathrm{O})$ has been found to play a critical role in the formation of secondary supramolecular architectures.
\end{abstract}

Keywords. Hydrogen bond; 2-aminothiazole; dihydroxybenzoic acids; salts; robust synthon.

\section{Introduction}

Crystal engineering has drawn the attention of the scientific community over the last two decades and it emerged as an archetype for supramolecular synthesis. Moreover, various applications, e.g., NLO, ${ }^{1}$ solvent free organic synthesis, ${ }^{2}$ host-guest chemistry, ${ }^{3}$ photographic film formulation, ${ }^{4}$ material science (supramolecular gels) ${ }^{5}$ were studied from crystal engineering perspective.

Properties of any material depend on the arrangement of molecules and their orientation in the crystal lattice. Thus, the role of intermolecular interactions is instrumental for imparting desired properties to the molecule. Therefore, a detailed study of the chemistry of molecules and interactions that constitute the crystal packing has been of prime importance in the field of crystal engineering. The supramolecular synthon ${ }^{6}$ approach using the CSD (Cambridge Structural Database) is an important tool for crystal engineers to select molecules/coformers by identification of robust/reliable synthon.

Thiazole is incorporated in vitamin B1 (thiamine) that is used in the production of DNA and RNA. ${ }^{7}$ It is also used as a coenzyme TPP (thiamine pyrophosphate)

*For correspondence for conversion of pyruvate to acetyl coenzyme A which is one of the steps in carbohydrate metabolism. ${ }^{8}$ Aminothiazoles have applications both in human and veterinary medicines ${ }^{9}$ and are familiar for anti-viral, ${ }^{10}$ anti-bacterial, ${ }^{11}$ anti-inflammatory ${ }^{12}$ and anti-cancer ${ }^{13}$ activities. The study of the influence of amino functional group on the activity of 2-amino histamine derivatives proved the ability of 2-aminothiazole to form proton transfer complexes and hence 2-amino histamine serves as 'molecular model'. ${ }^{14}$ The thiazole $\mathrm{N}$ (ring $\mathrm{N}$ of 2-aminothiazole) corresponds to the N1 of 2amino histamine (scheme 1) and the amine $\mathrm{N}$ (exocyclic $\mathrm{N}$ ) of the 2-aminothiazole relates to that of N3 nitrogen of 2-amino histamine.

The cocrystals/salts of different aminobenzothiazole derivatives with various carboxylic acid coformers have been reported in the literature. ${ }^{15,16}$ The salts of 2-aminothiazole were reported with trichloroacetic acid, ${ }^{17}$ 3,5-dinitrobenzoic acid, 3,5-dinitrosalicylic acid, ${ }^{18}$ indole-2-carboxylic acid, N-methylpyrrole-2carboxylic acid and thiophene-2-carboxylic acid. ${ }^{19}$ The two point supramolecular synthon was observed through $\mathrm{N}-\mathrm{H} \cdots \mathrm{O}^{-}$and $\mathrm{N}^{+}-\mathrm{H} \cdots \mathrm{O}^{-}$hydrogen bonds in all the reported salts/cocrystals. The $\mathrm{R}_{2}^{2}(8)$ graph set dimer association was observed between amine/heterocyclic $\mathrm{N}$ sites and complementary carboxylate groups in all the resultant salts/cocrystals. 


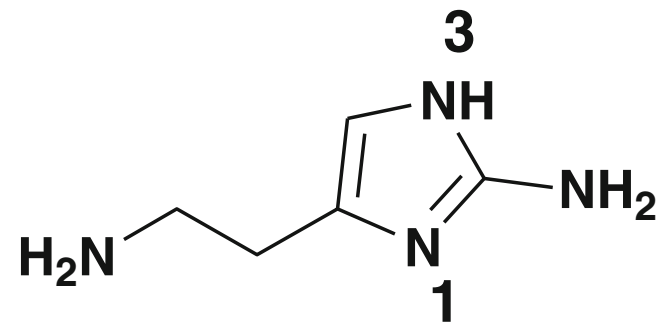

Scheme 1. Molecular structure of 2-amino histamine.

Thiazole is a core moiety in APIs like sulfathiazole ${ }^{20}$ and meloxicam ${ }^{21}$ that are known for their anti-bacterial activity and have been studied extensively. However, the study of hydrogen bonding and other non-covalent interactions still remains less explored. In addition, numerous salts of type $\left(\mathrm{NH}_{3}^{+} \ldots \mathrm{COO}^{-}\right)^{22}$ in comparison to few salts of type $\mathrm{N}^{+}-\mathrm{H}$ (heterocycle) $\cdots \mathrm{O}^{-}$ have been reported in the literature. Hence, it is interesting to explore the robust synthon formation when diverse functional groups (e.g., amines, Nheterocycles, phenols, carboxylates, etc.) are present simultaneously. Acid-heterocyclic amine (imidazole $)^{23}$ and amino-phenol ${ }^{24}$ synthons have been studied for crystal design due to their complementary nature. Further, $\mathrm{COOH} \cdot \cdots$ pyN synthon had been widely studied (energetically more favoured), ${ }^{25}$ however, it is relatively of less biological relevance. Hence, it has been proposed to study $\mathrm{COOH}$... thiazoleN synthon which has more application in biology than $\mathrm{COOH} \cdots$ pyN synthon.

Carboxylic acids were chosen for this study because they are recognized as robust coformers due to the presence of hydrogen bond donating as well as accepting sites. They are potential candidates in forming dimers and catemers by self-association and supramolecular heterosynthons with the complementary functional groups (acid-amide, acid-pyridine, etc.).

In this regard, attempts have been made to synthesize salts of 2-aminothiazole with six carboxylic acids coformers namely, benzoic acid, 2,3-, 2,4-, 2,5-, 2,6-dihydroxybenzoic acids and 2,4-dinitrobenzoic acid (scheme 2) to compare the hydrogen bonding pattern and supramolecular interactions in resultant salts.

\section{Experimental}

\subsection{Materials and general methods}

The coformers were purchased from Sigma-Aldrich and the 2-aminothiazole was procured from Spectrochem<smiles>Nc1nccs1</smiles>

(1)<smiles>O=C(O)c1c(O)cccc1O</smiles>

(d)<smiles>O=C(O)c1cccc(O)c1O</smiles>

(a)<smiles>O=C(O)c1ccc([N+](=O)[O-])cc1[N+](=O)[O-]</smiles>

(e)<smiles>O=C(O)c1ccc(O)cc1O</smiles>

(b)<smiles>O=C(O)c1ccccc1</smiles>

(f)<smiles>O=C(O)c1cc(O)ccc1O</smiles>

(c)
Scheme 2. Pharma intermediate and coformers used in the present study: 2-aminothiazole (1) 2,3-dihydroxybenzoic acid (a), 2,4-dihydroxybenzoic acid (b), 2,5- dihydroxybenzoic acid (c) 2,6-dihydroxybenzoic acid (d) 2,4dinitrobenzoic acid (e), benzoic acid (f).

Chemicals. The FT-IR spectra were recorded by the Nicolet Avatar 330 instrument in the range 4000$400 \mathrm{~cm}^{-1}$. Differential scanning calorimetry (DSC) was recorded on a Shimadzu DSC-60 instrument with a heating rate of $10^{\circ} \mathrm{C} / \mathrm{min}$. NMR was recorded on Bruker, Avance II $(500 \mathrm{MHz})$ with TMS as internal reference. XRPD was recorded on JEOL JDX$8 \mathrm{P}-\mathrm{XRD}$ in the range $5^{\circ}-50^{\circ}$ at the scan rate of $2^{\circ} / \mathrm{sec}$.

\section{$2.2 X$-ray crystallography}

X-ray intensity data were collected for compounds $\mathbf{1 a}, \mathbf{1 b}, \mathbf{1 c}$ and $\mathbf{1 d}$ at room temperature using Oxford $X$ Calibur, Gemini diffractometer equipped with EOS CCD detector. Monochromatic Mo- $K_{\alpha}$ radiation $(\lambda=$ $0.71073 \AA$ ) was used for the measurements. Data were collected and reduced using the 'CrysAlispro' program. ${ }^{26}$ An empirical absorption correction using spherical harmonics was implemented in 'SCALE3 ABSPACK' scaling algorithm. Bruker SMART APEX CCD diffractometer using graphite monochromated Mo- $K_{\alpha}$ radiation $(\lambda=0.71073 \AA$ ) was used for compound 1e and BRUKER AXS KAPPA APEX 2 CCD diffractometer using graphite monochromated Mo- $K_{\alpha}$ radiation $(\lambda=0.71073 \AA)$ was used for compound 1f. The data integration and reduction were carried out using SAINT-PLUS ${ }^{27}$ software. An empirical absorption correction was applied to the collected reflections with SADABS. All the six structures were solved by direct methods using SHELXS $97^{28}$ and refinement was carried out by full-matrix least-squares 
technique using SHELXL97. Anisotropic displacement parameters were calculated for all non-hydrogen atoms. $\mathrm{H}$ atoms attached to the $\mathrm{N}$ (amine and heterocycle) atoms were located in a difference Fourier density map and refined isotropically. All the aromatic hydrogen atoms $(\mathrm{C}-\mathrm{H})$ were placed in calculated positions and refined isotropically using a riding model.

\subsection{Procedure for preparation of the salts}

2.3a 2-aminothiazolium-2,3-dihydroxybenzoate (1a): A mixture of 2-aminothiazole $(200 \mathrm{mg}, 2 \mathrm{mmol})$ and 2,3-dihydroxybenzoic acid (307 $\mathrm{mg}, 2 \mathrm{mmol}$ ) was dissolved in $4 \mathrm{~mL}$ mixture of (1:1) acetone and methanol and heated under mild conditions followed by slow evaporation at room temperature. Plate shaped colourless crystals were obtained in 2 days.

$2.3 b \quad 2$-aminothiazolium-2,4-dihydroxybenzoate (1b): A mixture of 2-aminothiazole $(50 \mathrm{mg}, 0.5 \mathrm{mmol})$ and 2,4-dihydroxybenzoic acid (77 $\mathrm{mg}, 0.5 \mathrm{mmol})$ was dissolved in $5 \mathrm{~mL}$ of methanol and sonicated followed by slow evaporation at room temperature. Pale yellow coloured block shaped crystals were obtained in 1 day.

2.3c 2-aminothiazolium-2,5-dihydroxybenzoate (1c): A mixture of 2-aminothiazole $(200 \mathrm{mg}, 2 \mathrm{mmol})$ and 2,5-dihydroxybenzoic acid ( $307 \mathrm{mg}, 2 \mathrm{mmol})$ was dissolved in $4 \mathrm{~mL}$ mixture of (1:1) acetone and methanol and heated under mild conditions followed by slow evaporation at room temperature. Pale yellow coloured block shaped crystals were obtained in 3 days.

2.3d 2-aminothiazolium-2,6-dihydroxybenzoate (1d): A mixture of 2-aminothiazole $(50 \mathrm{mg}, 0.5 \mathrm{mmol})$ and 2,6-dihydroxybenzoic acid ( $77 \mathrm{mg}, 0.5 \mathrm{mmol})$ was dissolved in $5 \mathrm{~mL}$ of methanol and sonicated followed by slow evaporation at room temperature. Pale yellow coloured plate shaped crystals were obtained in 4 days.

(a)

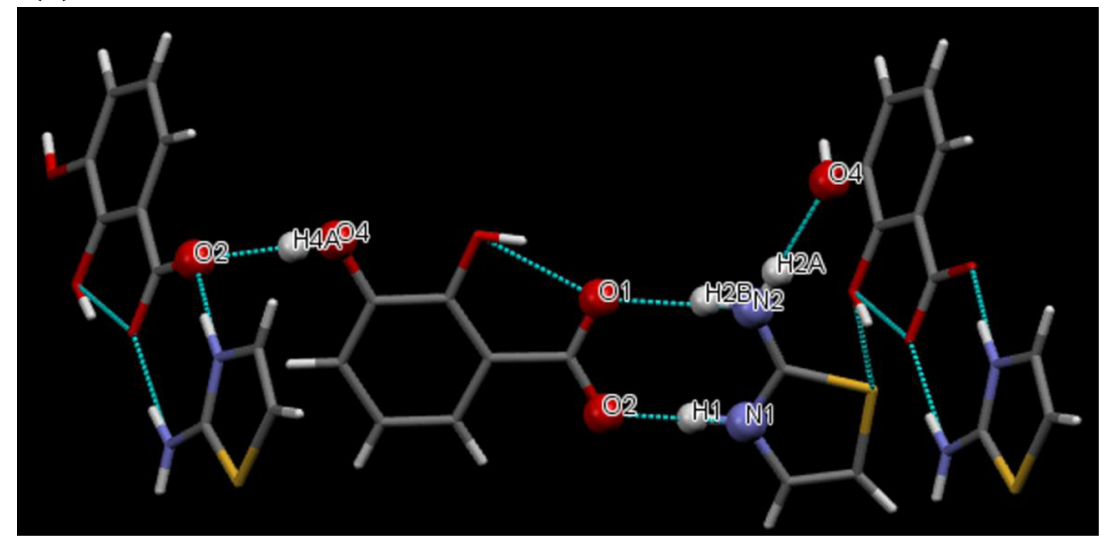

(b)

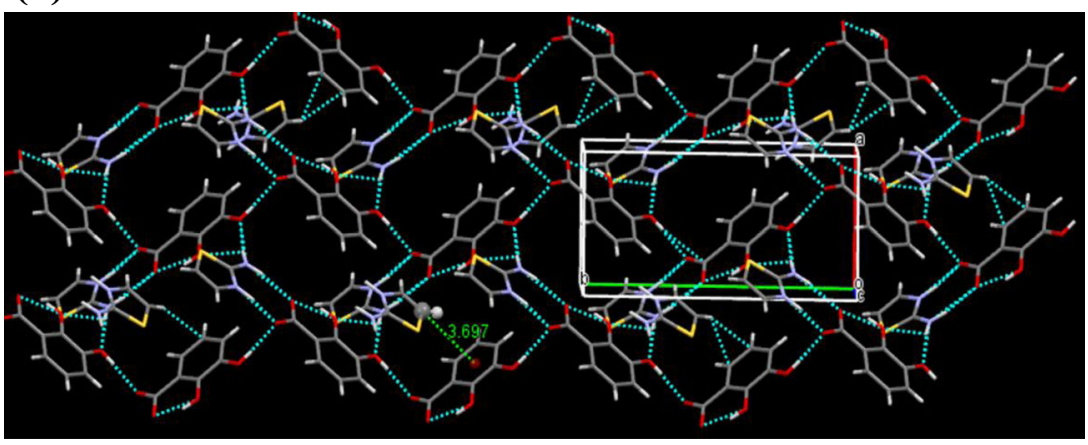

Figure 1. (a) The dimers interconnected by $\mathrm{N}-\mathrm{H} \cdots \mathrm{O}$ and $\mathrm{O}-\mathrm{H} \cdots \mathrm{O}$ hydrogen bonds in 1a and (b) 2D zigzag chain stabilized by secondary interactions in $\mathbf{1 a}$. 
2.3e 2-aminothiazolium-2,4-dinitrobenzoate (1e): A mixture of 2-aminothiazole $(200 \mathrm{mg}, 2 \mathrm{mmol})$ and 2,4dinitrobenzoic acid (424 mg, $2 \mathrm{mmol}$ ) was dissolved in $5 \mathrm{~mL}$ mixture of (4:1) methanol and DMSO, heated under mild conditions followed by slow evaporation at room temperature. Pale yellow coloured plate shaped crystals were obtained in 15 days.

2.3f 2-aminothiazolium-benzoate (1f): A mixture of 2-aminothiazole (50 mg, $0.5 \mathrm{mmol})$ and of benzoic acid (61 mg, $0.5 \mathrm{mmol}$ ) was dissolved in $5 \mathrm{~mL}$ mixture of (1:1) methanol and ethanol, sonicated, followed by slow evaporation at room temperature. Block shaped colourless crystals were obtained in 3 days.

\section{Results and Discussion}

\section{$3.1 \quad 1 a$}

1a was found to crystallize in $\mathrm{P} 2{ }_{1} / \mathrm{c}$ space group with one 2-aminothiazole and one 2,3-dihydroxybenzoic acid molecule in the asymmetric unit. The carboxylic acid protonated the amine via $\mathrm{O}^{-} \cdots \mathrm{H}-\mathrm{N}^{+}$ hydrogen bond $2.652(3) \AA$, protonated $\mathrm{N}$ (azole), $\mathrm{N}-\mathrm{H} 1.01(3) \AA$, the $\mathrm{O} \cdots \mathrm{H} 1.66(3) \AA, \angle \mathrm{O} \cdots \mathrm{H}-\mathrm{N}$ $169(3)^{\circ}$ and $\mathrm{N}-\mathrm{H} \cdots \mathrm{O}^{-}, \mathrm{N} \cdots \mathrm{O} 2.869(3) \AA, \mathrm{H} \cdots \mathrm{O}$ $1.97(3) \AA, \angle \mathrm{N}-\mathrm{H} \ldots \mathrm{O} \quad 171(3)^{\circ}$ (figure 1a). The dimers were interconnected with each other by $\mathrm{O}-\mathrm{H}\left(\right.$ hydroxyl) $\ldots \mathrm{O}^{-} \quad$ (carboxylate) 2.653(2) $\AA$ hydrogen bond, $\mathrm{N}-\mathrm{H}$ (amine)... O (hydroxyl) hydrogen bond, 2.872(4) $\AA$ and S . . O , 3.316(3) $\AA$ interactions (figure 1a). The secondary interaction $\mathrm{C}-\mathrm{H}$ (thiazole) $\cdots \pi$ (coformer) $3.697 \AA$ (figure 1b), further stabilized the 2D zigzag chains as shown in figure $1 \mathrm{~b}$.

\section{$3.2 \mathbf{1 b}$}

1b was found to crystallize in monoclinic space group $\mathrm{P} 2{ }_{1} / \mathrm{c}$ with one 2-aminothiazole and one 2,4dihydroxybenzoic acid molecule in the asymmetric unit. The ion pair was held by $\mathrm{O}^{-} \cdots \mathrm{H}-\mathrm{N}^{+}$hydrogen

(a)

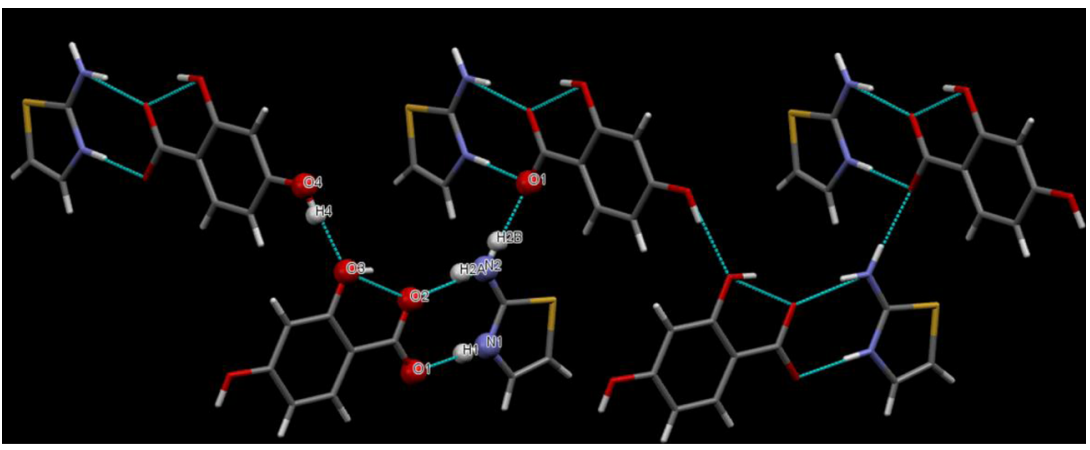

(b)

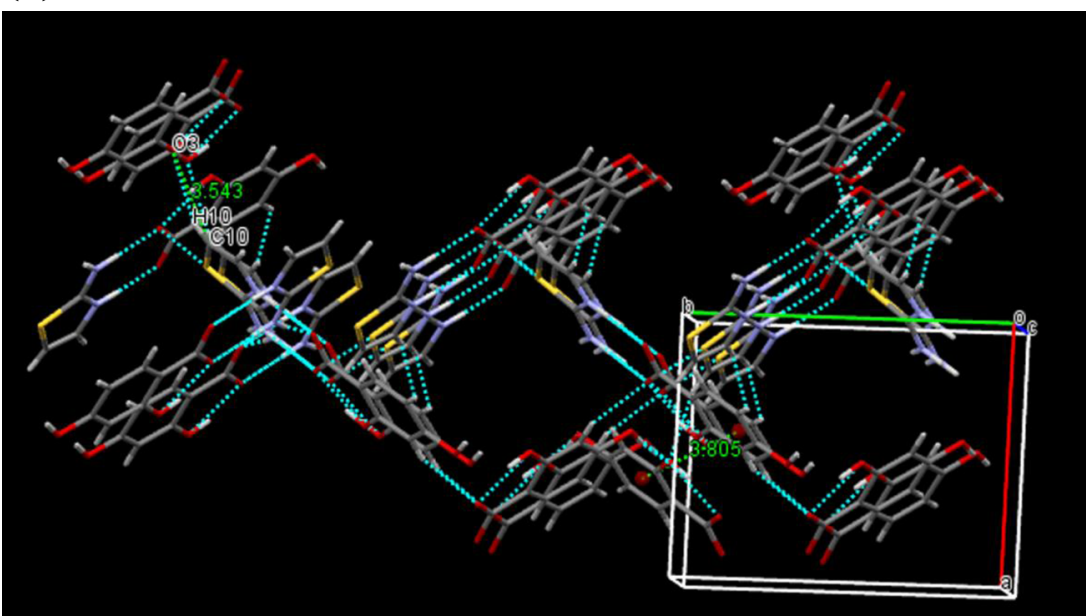

Figure 2. (a) The supramolecular adducts sustained through heterosynthons that form 1D zigzag chain in 1b and (b) 3D Basket weave network observed in $\mathbf{1 b}$. 
bond 2.678(3) $\AA$, protonated N(azole), N-H 0.861(2) $\AA$, the $\mathrm{O} \cdots \mathrm{H} 1.819(2) \AA, \angle \mathrm{O} \cdots \mathrm{H}-\mathrm{N} 176.2(1)^{\circ}$ and $\mathrm{N}-\mathrm{H} \cdots \mathrm{O}^{-}, \mathrm{N} \cdots \mathrm{O} \quad 2.780(3) \AA, \mathrm{H} \cdots \mathrm{O}$ 1.940(2) $\AA$, $\angle \mathrm{N}-\mathrm{H} \cdots \mathrm{O} 165(2)^{\circ}$ (figure 2a). The dimer was connected to the adjacent dimers by $\mathrm{O}-\mathrm{H}($ hydroxyl)... O(hydroxyl of other coformer), 2.769(2) $\AA$ and $\mathrm{N}-\mathrm{H}$ (amine) $\cdots \mathrm{O}^{-}$(carboxylate), 2.764(3) $\AA$ hydrogen bonds (figure 2a) that lead to 1D zigzag chains (figure 2a). The 1D chains repeated and resulted in basket weave pattern as shown in figure $2 b$. The weak $\mathrm{C}-\mathrm{H}$ (thiazole) $\cdots \mathrm{O}$ (coformer) 3.543(3) $\AA$ interaction and $\mathrm{O}$...S 3.281(3) $\AA$ short contacts further stabilized the 3D network. In addition, $\pi-\pi$ stacking interaction was observed between two coformers from the adjacent layers with the centroid-centroid distance of $3.805 \AA$.

\section{$3.31 c$}

1c was found to crystallize in tetragonal space group I $4_{1} / \mathrm{a}$ with one ion pair (2-aminothiazole and 2,5dihydroxybenzoic acid) in the asymmetric unit. The carboxyl $\mathrm{O}$ of the coformer was hydrogen bonded to thiazole $\mathrm{N}$ via $\mathrm{O}^{-} \cdots \mathrm{H}-\mathrm{N}^{+}$2.703(2) $\AA$, the $\mathrm{O} \cdots \mathrm{H} \quad 1.858(2) \AA, \angle \mathrm{O} \cdots \mathrm{H}-\mathrm{N} \quad 166.7(1)^{\circ}$. The $\mathrm{O}$ of carboxylate (of coformer) was involved in the hydrogen bond to amine $\mathrm{N}$ through $\mathrm{O}^{-} \cdots \mathrm{H}-\mathrm{N}$

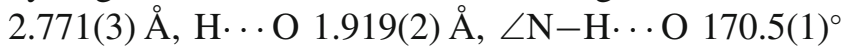
(figure $3 \mathrm{a})$. The ion pair was connected to neighbouring dimers by $\mathrm{N}-\mathrm{H}($ amine $) \cdots \mathrm{O}^{-}$(carboxylate) 2.767(2) $\AA$ and O-H(hydroxyl) . . O (hydroxyl of other coformer) 2.770 (2) Å hydrogen bonds (figure 3a) which in turn formed a layered sheet that was stabilized by

(a)

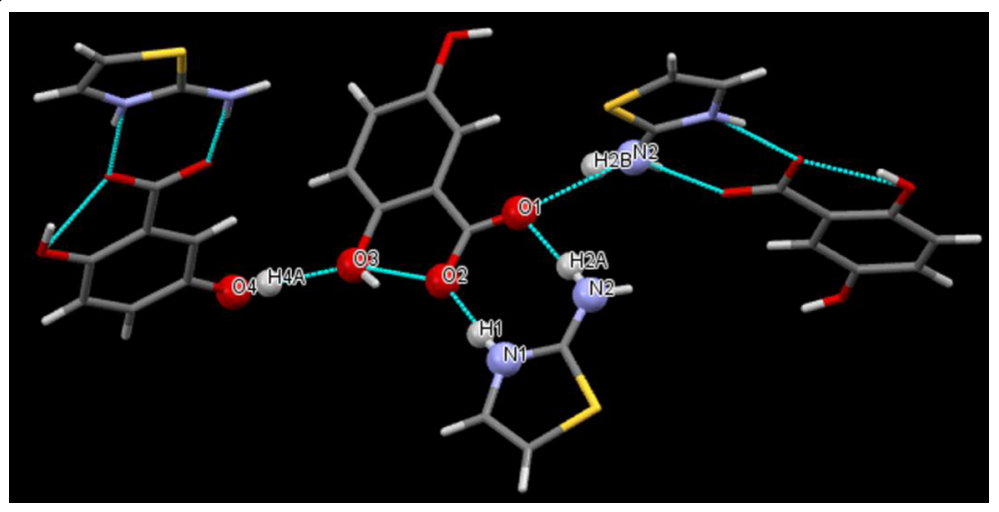

(b)

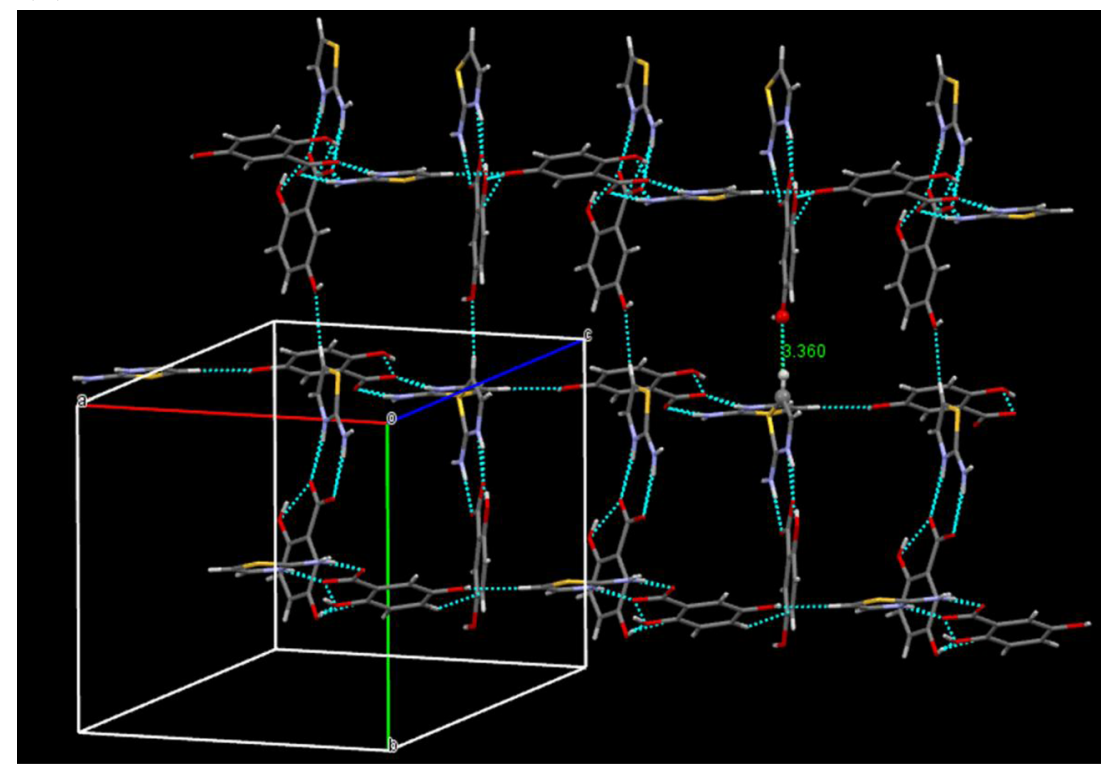

Figure 3. (a) The hydrogen bonding pattern in $\mathbf{1 c}$ and (b) the supramolecular sheet stabilized by $\mathrm{C}-\mathrm{H}$ (thiazole) $\cdots \mathrm{O}$ (hydroxy) interaction in 1c. 
C-H(thiazole) . . O (hydroxyl of coformer) 3.360(3) $\AA$ interaction (figure 3b).

\section{$3.41 d$}

The asymmetric unit in the crystal structure (monoclinic $\mathrm{C} 2 / \mathrm{c}$ ) of $\mathbf{1 d}$ comprised of one 2-aminothiazole and one 2,6-dihydroxybenzoic acid molecule. The adduct was found to be salt and was interconnected by $\mathrm{O}^{-} \cdots \mathrm{H}-\mathrm{N}^{+}$2.641(2) $\AA$, the $\mathrm{O} \cdots \mathrm{H}$

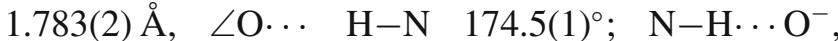
$\mathrm{N} \cdots \mathrm{O} \quad 2.844(3) \AA, \mathrm{H} \cdots \mathrm{O} \quad 1.996(2) \AA, \angle \mathrm{N}-\mathrm{H} \cdots \mathrm{O}$ $168.8(2)^{\circ}$ hydrogen bonds (figure $\left.4 \mathrm{a}\right)$. The ion pair was transformed to a $1 \mathrm{D}$ zigzag chain (figure 4a) through $\mathrm{N}$ (amine) $-\mathrm{H}$. . O (hydroxy) hydrogen bond. The 1D chains were connected by $\mathrm{C}-\mathrm{H} \cdots \mathrm{O}$ 3.239(3) $\AA$ and $\mathrm{C}-\mathrm{H}$ (thiazole) $\cdots \pi$ (coformer) $3.615 \AA$ secondary interactions resulting in herringbone packing (figure 4b).

\section{$3.51 e$}

1e was found to crystallize in $\mathrm{P} 2{ }_{1} / \mathrm{c}$ space group and the asymmetric unit comprised of one molecule of 2-aminothiazole and 2,4-dinitrobenzoic acid. The proton transfer complex was held by $\mathrm{O}^{-} \cdots \mathrm{H}-\mathrm{N}^{+}$ hydrogen bond $2.816(3) \AA$, protonated $\mathrm{N}, \mathrm{N}-\mathrm{H}$ $0.820(3) \AA$, the $\mathrm{O} \cdots \mathrm{H} \quad 2.01(3) \AA, \quad \angle \mathrm{O} \cdots \mathrm{H}-\mathrm{N}$ $168.48(2)^{\circ}$ and $\mathrm{N}-\mathrm{H} \cdots \mathrm{O}^{-}$hydrogen bond, $\mathrm{N} \cdots \mathrm{O}$ 2.778(3) $\mathrm{A}, \mathrm{H} \cdots \mathrm{O} 1.973(2) \AA, \angle \mathrm{N}-\mathrm{H} \cdots \mathrm{O} 155.4(1)^{\circ}$ (figure 5a). The dimer was connected to the adjacent dimer by $\mathrm{O} \cdots \mathrm{O} 2.943(2) \AA$, O . . S 3.148(2) short contacts and $\mathrm{N}-\mathrm{H} \cdots \mathrm{O}, 2.876(3) \AA$ hydrogen bond (figure 5a) to form cyclic heterotetramer. The tetramers recurred to form a 3D network, which was stabilized by the $\mathrm{C}-\mathrm{H}$ (thiazole) $\cdots \mathrm{O}$ (nitro) interactions 3.549(3) $\AA$ (figure 5b). Further, $\pi-\pi$ stacking interactions were observed between two coformers with centroid-centroid distance of $3.919 \AA$.

(a)

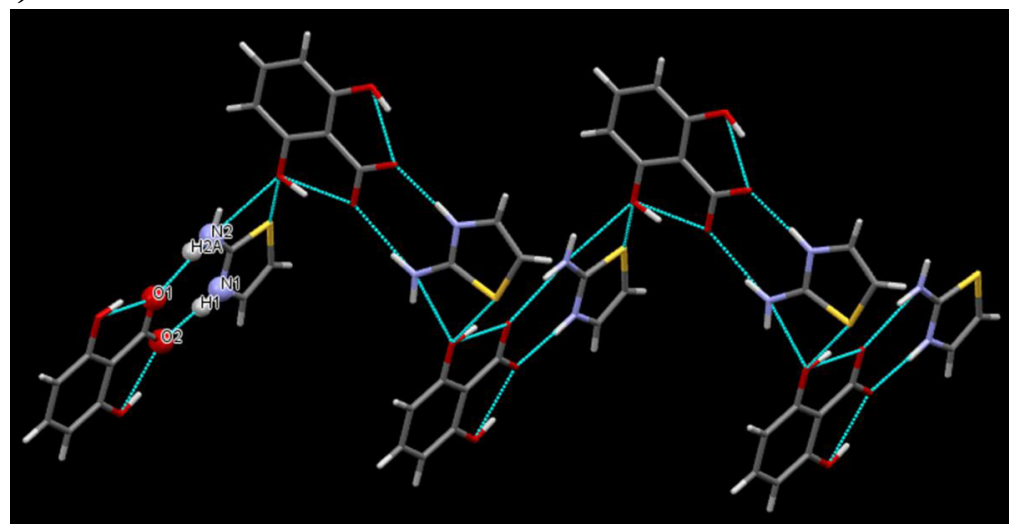

(b)

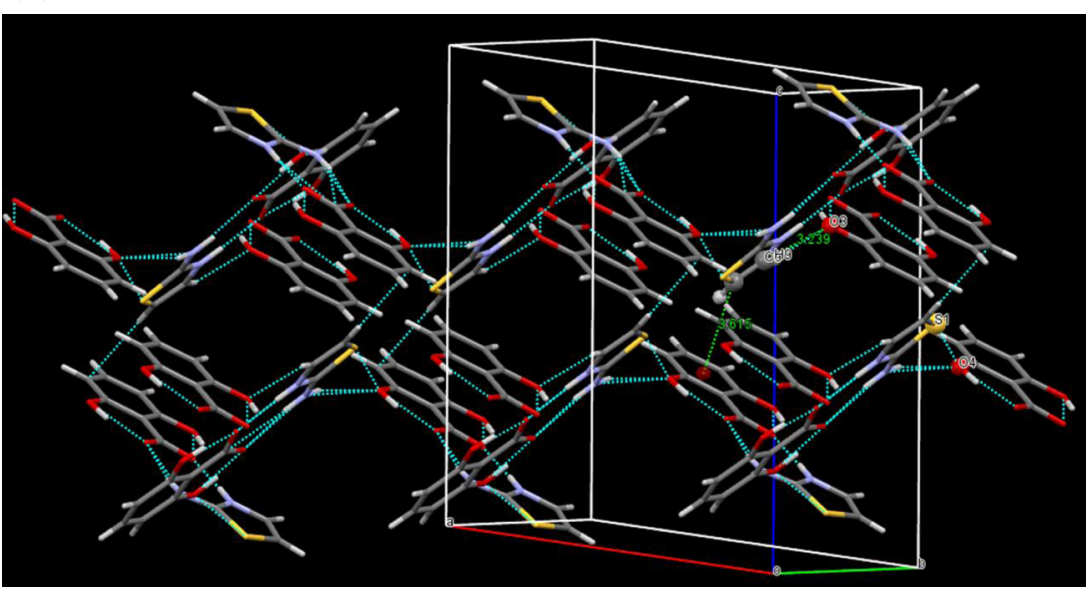

Figure 4. (a) One dimensional zigzag chain in 1d and (b) 1D chains held by secondary interactions thus resulting in Herringbone packing in $\mathbf{1 d}$. 
(a)

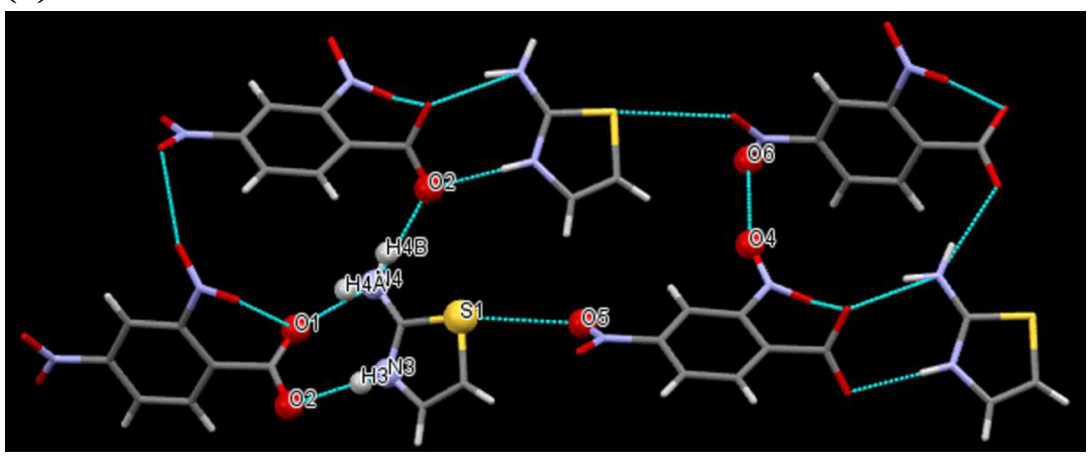

(b)

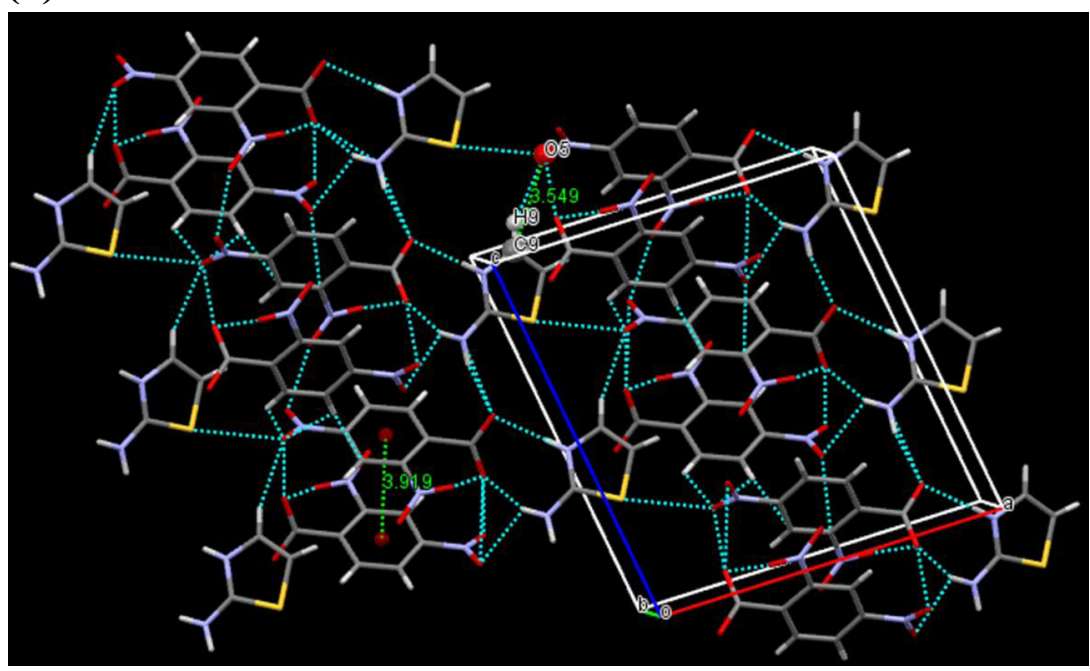

Figure 5. (a) Interlinking of dimers through $\mathrm{N}-\mathrm{H} \cdots \mathrm{O}$ hydrogen bond, $\mathrm{S} \ldots \mathrm{O}$ and $\mathrm{O} \cdots \mathrm{O}$ short contacts to form cyclic heterotetramer in $\mathbf{1 e}$ and (b) 3D network stabilized by secondary interactions in $\mathbf{1 e}$.

\subsection{If}

1f was found to crystallize in $\mathrm{C} 2 / \mathrm{c}$ space group with one each molecule of 2-aminothiazole and benzoic acid in the asymmetric unit. The proton transfer was noticed from carboxylic acid to the 2-aminothiazole through $\mathrm{O}^{-} \cdots \mathrm{H}-\mathrm{N}^{+}$hydrogen bond $2.662(2) \AA$, protonated $\mathrm{N}, \mathrm{N}-\mathrm{H} \quad 0.91(2) \AA$, the $\mathrm{O} \cdots \mathrm{H} 1.76(2) \AA$, $\angle \mathrm{O} \cdots \mathrm{H}-\mathrm{N} 175(2)^{\circ}$ and $\mathrm{N}-\mathrm{H} \cdots \mathrm{O}^{-}$hydrogen bond, $\mathrm{N} \cdots \mathrm{O} \quad 2.744(2) \AA, \quad \mathrm{H} \cdots \mathrm{O} \quad 1.86(2) \AA, \quad \angle \mathrm{N}-\mathrm{H} \cdots \mathrm{O}$ $172(2)^{\circ}$ (figure $\left.6 a\right)$. The dimer was connected to the neighbouring dimers by $\mathrm{N}-\mathrm{H}$ (amine) $\cdots \mathrm{O}^{-}$(carboxylate), 2.783(2) $\AA$ hydrogen bond (figure 6a) that duplicate to form a ' $\mathrm{V}$ ' shaped $2 \mathrm{D}$ network stabilized by (thiazole) $\pi-\pi$ (coformer) $3.755 \AA$ and $\mathrm{C}-\mathrm{H}$ (thiazole)... O (carboxylate) $3.427(2) \AA$ interactions (figure 6b).

By convention, a primary amine and monocarboxylic acid combination results in salt of type $\mathrm{NH}_{3}^{+} \ldots \mathrm{COO}^{-}$.
The possible primary ammonium monocarboxylate synthons are shown in scheme 3 .

However, it has been revealed from the reported salts of 2-aminothiazole in the literature that it doesn't follow the convention type supramolecular synthon due to the two plausible tautomeric forms (amine and imine, scheme 4).

In polar solvents, the imine form of 2-aminothiazole is energetically more stable and favourable. Due to the higher basicity of the exocyclic nitrogen, protonation occurred (at the terminal exocyclic nitrogen) resulting in the salt formation. As the solvents used in the present study were polar, the net result was the salt formation with protonation at 'aza' nitrogen. The same trend was observed in all the reported salts though competitive functional group like hydroxyl $(-\mathrm{OH}) /$ nitro $\left(-\mathrm{NO}_{2}\right)$ were present at different position in the coformers.

The difference $\Delta \mathrm{r}$ (difference between the $\mathrm{C}-\mathrm{O}$ distances of carboxylate) being less than $0.03 \AA$ confirmed 
(a)

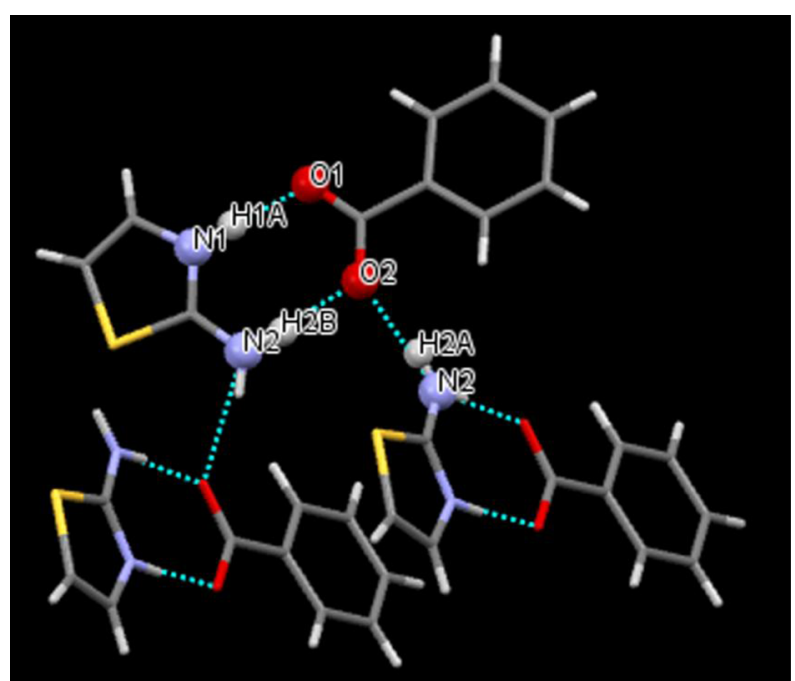

(b)

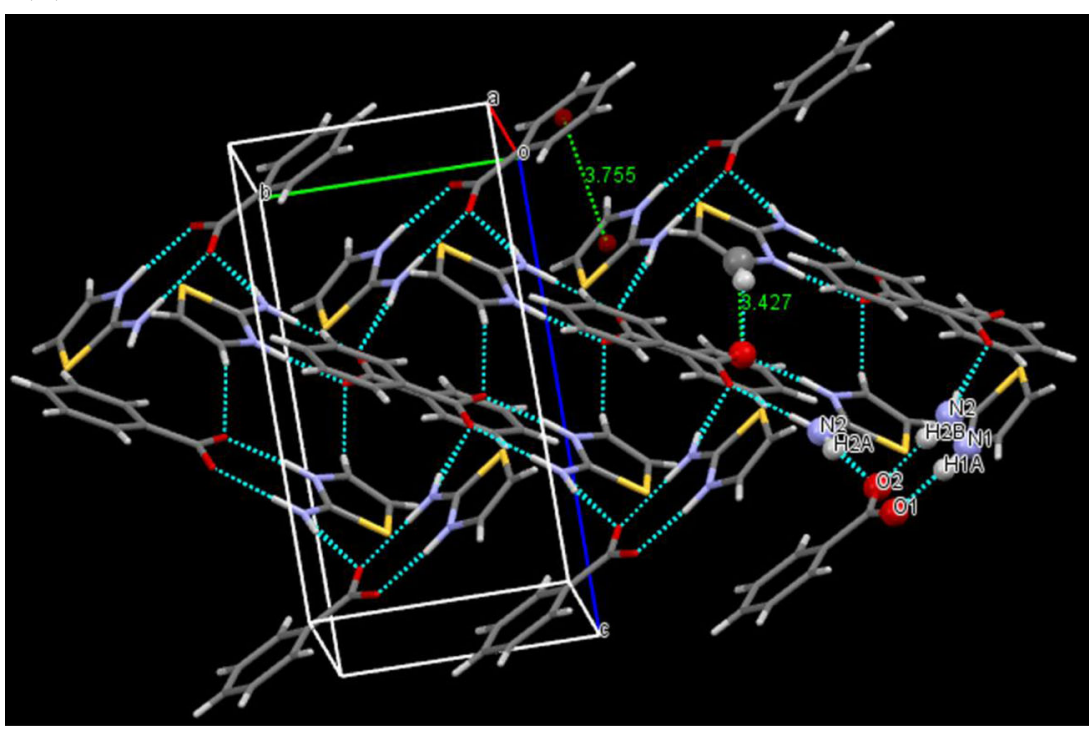

Figure 6. (a) Two point supramolecular synthon in $\mathbf{1 f}$ and (b) "V" shaped 2D network in $\mathbf{1 f}$.

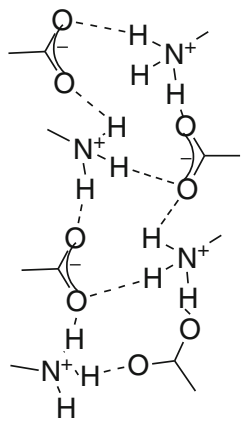

(a)

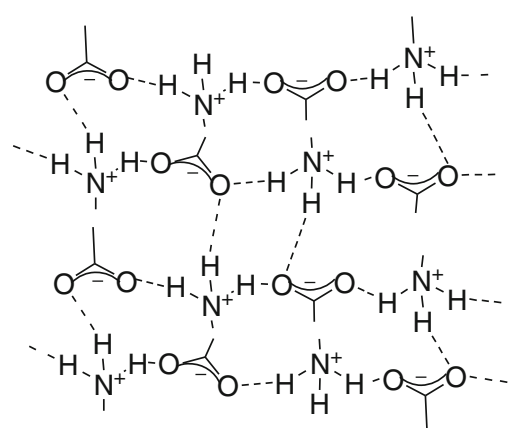

(b)
Scheme 3. Primary ammonium monocarboxylate synthons (a) $1 \mathrm{D}$ synthon (b) 2D synthon. the presence of the carboxylate anion in all reported salts (1a-1f, table 1).

The salt 1c displayed considerable $\Delta \mathrm{r}$ difference $(0.022 \AA)$ unlike $\mathbf{1 a}$ and $\mathbf{1 b}$ where the difference was only $0.003 \AA$ and $0.013 \AA$ respectively. This could be due to the relatively higher deviation of the carboxylate

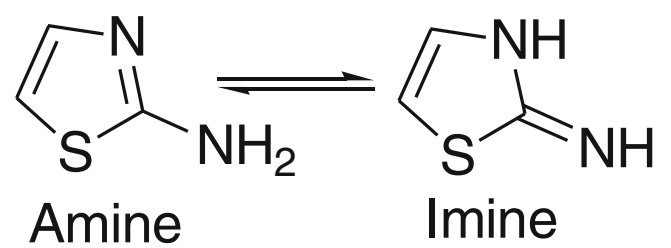

Scheme 4. Tautomeric forms of 2-aminothiazole. 
Table 1. Carboxyl and carboxylate bond lengths observed in salts $\mathbf{1 a}-\mathbf{1 f}$.

\begin{tabular}{lcc}
\hline Salt & $\mathrm{d}(\mathrm{C}=\mathrm{O}) \AA$ & $\mathrm{d}(\mathrm{C}-\mathrm{O}) \AA$ \\
\hline $\mathbf{1 a}$ & $1.260(4)$ & $1.263(3)$ \\
$\mathbf{1 b}$ & $1.257(2)$ & $1.270(3)$ \\
$\mathbf{1 c}$ & $1.242(3)$ & $1.268(3)$ \\
$\mathbf{1 d}$ & $1.263(4)$ & $1.264(4)$ \\
$\mathbf{1 e}$ & $1.230(3)$ & $1.245(2)$ \\
$\mathbf{1 f}$ & $1.252(2)$ & $1.255(2)$ \\
\hline
\end{tabular}

Table 2. Comparison of $\mathrm{N}^{+}-\mathrm{H} \cdots \mathrm{O}^{-}$distance with $\Delta \mathrm{r}$ and $\Delta \mathrm{p} K_{\mathrm{a}}$ in the salts 1a-1f.

\begin{tabular}{lccc}
\hline Salt & $\Delta \mathrm{p} K_{\mathrm{a}}$ & $\Delta \mathrm{r}=\mathrm{d} 1-\mathrm{d} 2 / \mathrm{d} 2-\mathrm{d} 1(\AA)$ & $\mathrm{d}\left(\mathrm{N}^{+}-\mathrm{H} \cdots \mathrm{O}^{-}\right) \AA$ \\
\hline 1a & 2.45 & 0.003 & $2.652(3)$ \\
1b & 2.17 & 0.013 & $2.678(3)$ \\
1c & 2.44 & 0.026 & $2.703(2)$ \\
1d & 4.17 & 0.001 & $2.641(2)$ \\
1e & 3.96 & 0.015 & $2.816(3)$ \\
1f & 1.19 & 0.003 & $2.662(2)$ \\
\hline
\end{tabular}

(in 1c) from the plane by an angle of $3.8^{\circ}$ whereas in $\mathbf{1 a}$ and $\mathbf{1 b}$, the carboxylate deviated from the plane by an angle of $2.5^{\circ}$ and $2.8^{\circ}$. In $\mathbf{1 d}$, owing to the presence of two hydroxyl groups at $2^{\text {nd }}$ and $6^{\text {th }}$ position (adjacent to carboxylate) the distortion of the carboxylate was hindered and hence the prominent delocalization is evident by $\Delta \mathrm{r}$ value $(0.001 \AA)$. Similarly, in the salt 1a, presence of the two hydroxyl groups nearer to

Table 3. Crystallographic data for salts of 2-aminothiazole and substituted benzoic acids (1a-1f).

\begin{tabular}{|c|c|c|c|c|c|c|}
\hline Organic salts & $1 \mathbf{a}$ & $1 b$ & $1 \mathrm{c}$ & $1 d$ & 1e & 1f \\
\hline CCDC number & 919166 & 919167 & 919168 & 919169 & 919171 & 924125 \\
\hline Formula & $\mathrm{C}_{10} \mathrm{H}_{10} \mathrm{~N}_{2} \mathrm{O}_{4} \mathrm{~S}$ & $\mathrm{C}_{10} \mathrm{H}_{10} \mathrm{~N}_{2} \mathrm{O}_{4} \mathrm{~S}$ & $\mathrm{C}_{10} \mathrm{H}_{10} \mathrm{~N}_{2} \mathrm{O}_{4} \mathrm{~S}$ & $\mathrm{C}_{10} \mathrm{H}_{10} \mathrm{~N}_{2} \mathrm{O}_{4} \mathrm{~S}$ & $\mathrm{C}_{10} \mathrm{H}_{8} \mathrm{~N}_{4} \mathrm{O}_{6} \mathrm{~S}$ & $\mathrm{C}_{10} \mathrm{H}_{10} \mathrm{O}_{2} \mathrm{~N}_{2} \mathrm{~S}$ \\
\hline M & 254.26 & 254.26 & 254.26 & 254.26 & 312.26 & 222.26 \\
\hline Crystal system & Monoclinic & Monoclinic & Tetragonal & Monoclinic & Monoclinic & Monoclinic \\
\hline Space group & $\mathrm{P} 2{ }_{1} / \mathrm{c}$ & $\mathrm{P} 2{ }_{1} / \mathrm{c}$ & $\mathrm{I} 4_{1} / \mathrm{a}$ & $\mathrm{C} 2 / \mathrm{c}$ & $\mathrm{P} 2{ }_{1} / \mathrm{c}$ & $\mathrm{C} 2 / \mathrm{c}$ \\
\hline $\mathrm{a} / \AA ̊$ & $7.5822(5)$ & $9.482(6)$ & $13.9228(6)$ & $24.7349(15)$ & $12.1387(12)$ & $24.1970(6)$ \\
\hline $\mathrm{b} / \AA$ & $13.6722(7)$ & $11.0799(6)$ & $13.9228(6)$ & $5.5302(3)$ & $8.1895(8)$ & $7.0090(2)$ \\
\hline$c / \AA ̊$ & 13.0211(13) & $11.2396(7)$ & $22.9182(12)$ & $16.4403(10)$ & $13.2374(13)$ & $14.0190(4)$ \\
\hline$\alpha /^{\circ}$ & 90.00 & 90.00 & 90.00 & 90.00 & 90.00 & 90.00 \\
\hline$\beta /^{\circ}$ & $120.8276(6)$ & $109.606(7)$ & 90.00 & $91.160(6)$ & $98.168(2)$ & $116.1870(10)$ \\
\hline$\gamma /{ }^{\circ}$ & 90.00 & 90.00 & 90.00 & 90.00 & 90.00 & 90.00 \\
\hline Volume/A ${ }^{3}$ & $1158.59(15)$ & $1112.36(11)$ & $4442.6(3)$ & $2248.4(2)$ & $1302.6(2)$ & $2133.54(10)$ \\
\hline $\mathrm{Z}$ & 4 & 4 & 16 & 8 & 4 & 8 \\
\hline$D_{\text {calc }} / \mathrm{gcm}^{-3}$ & 1.458 & 1.518 & 1.521 & 1.502 & 1.592 & 1.384 \\
\hline$\mu / \mathrm{mm}^{-1}$ & 0.284 & 0.296 & 0.296 & 0.256 & 0.284 & 0.284 \\
\hline $\mathrm{T} / \mathrm{K}$ & $293(2)$ & 293(2) & $293(2)$ & 293(2) & $273(2)$ & 293(2) \\
\hline Reflns collected & 2369 & 2266 & 2267 & 2294 & 2559 & 1871 \\
\hline Unique reflns & 1405 & 1725 & 1627 & 1380 & 2349 & 1671 \\
\hline Parameters refined & 166 & 160 & 159 & 162 & 194 & 149 \\
\hline Goodness of fit $S$ & 1.033 & 1.037 & 1.018 & 0.918 & 1.121 & 1.085 \\
\hline $\mathrm{R}_{1}(\mathrm{I}>2 \sigma)$ & 0.0460 & 0.0478 & 0.0466 & 0.0519 & 0.0482 & 0.0291 \\
\hline $\mathrm{wR}_{2}(\mathrm{I}>2 \sigma)(\mathrm{I}>2 \sigma)$ & 0.0978 & 0.1123 & 0.0992 & 0.0843 & 0.1178 & 0.0730 \\
\hline $\begin{array}{l}\text { Largest diff. peak } \\
\text { and hole, } \mathrm{e} \AA^{-3}\end{array}$ & $0.13,-0.23$ & $0.39,-0.45$ & $0.18,-0.18$ & $0.19,-0.18$ & $0.37,-0.33$ & $0.18,-0.17$ \\
\hline
\end{tabular}


the carboxylate locked the distortion and hence prominent delocalization was observed $(\Delta r=0.003 \AA)$. The $\Delta \mathrm{r}$ or the extent of delocalization was also reflected in $\mathrm{N}^{+}-\mathrm{H} \cdots \mathrm{O}^{-}$bond distances and it was in the order of $\mathbf{1 d}<\mathbf{1 a}<\mathbf{1 b}<\mathbf{1 c}$ (table 2). In the salt $\mathbf{1 e}$, though delocalization was considerably greater, $(\Delta \mathrm{r}=$ $0.015 \AA)$, the $\mathrm{N}^{+}-\mathrm{H} \cdots \mathrm{O}^{-}$distance was high $(2.816 \AA)$ due to the presence of the bulky nitro group which induced the distortion of the carboxylate and hence the higher bond distance. Surprisingly, 1f followed a different trend where the carboxylate was distorted by an angle of $5.3^{\circ}$ and delocalization was prominent with $\Delta r=0.003 \AA$. The reason could be the absence of substitution in the benzene ring at $2^{\text {nd }}$ position and lack of any intramolecular hydrogen bonding short contacts.
Further, in the salts $\mathbf{1 a}$ and $\mathbf{1 b}$, the terminal nitrogen formed hydrogen bond with the ' $\mathrm{O}$ ' of carboxylate which was involved in $\mathrm{O} \cdots \mathrm{O}$ short contact with the hydroxyl (-OH) functional group at $2^{\text {nd }}$ position. However, in salt 1c the ring $\mathrm{N}$ was bonded to the $\mathrm{O}$ of carboxylate which in turn involved in $\mathrm{O} \cdots \mathrm{O}$ short contact. Hence, it can be explained that the preference of the hydrogen bonding (of the ' $\mathrm{O}$ ' of the carboxylate with either the terminal $\mathrm{N}$ or ring $\mathrm{N}$ ) have been affected by position of hydroxyl (-OH) substituent in the coformers.

The protonation of the azole $\mathrm{N}$ was evident by the $\mathrm{N}-\mathrm{H}$ distance which was similar to that of amine $\mathrm{N}$ and the increased $\mathrm{C}-\mathrm{N}-\mathrm{C}$ bond angle $\left(\sim 114^{\circ}\right)$ for all the reported salts compared to 2-aminothiazole $\left(109.4^{\circ}\right)$. The two point supramolecular heterosynthon is robust

Table 4. Metrics of the hydrogen bonds in the salts $\mathbf{1 a - 1 f}$.

\begin{tabular}{|c|c|c|c|c|c|}
\hline $\mathrm{D}-\mathrm{H} \cdots \mathrm{A}$ & $d(\mathrm{D}-\mathrm{H})$ & $d(\mathrm{H} \cdots \mathrm{A})$ & $\mathrm{D}(\mathrm{D} \cdots \mathrm{A})$ & $\angle \mathrm{DHA}$ & Symmetry Transformations \\
\hline \multicolumn{6}{|c|}{$1 \mathbf{a}$} \\
\hline $\mathrm{N} 1-\mathrm{H} 1 \cdots \mathrm{O} 2$ & $1.01(3)$ & $1.66(3)$ & $2.652(3)$ & $169(3)$ & $-\mathrm{x}+2,-\mathrm{y}+1,-\mathrm{z}+1$ \\
\hline $\mathrm{N} 2-\mathrm{H} 2 \mathrm{~A} \cdots \mathrm{O} 3$ & $0.88(3)$ & $2.58(3)$ & $3.114(3)$ & $120(2)$ & $\mathrm{x},-\mathrm{y}+3 / 2, \mathrm{z}+1 / 2$ \\
\hline $\mathrm{N} 2-\mathrm{H} 2 \mathrm{~A} \cdots \mathrm{O} 4$ & $0.88(3)$ & $2.00(3)$ & $2.872(4)$ & 171(3) & $\mathrm{x},-\mathrm{y}+3 / 2, \mathrm{z}+1 / 2$ \\
\hline $\mathrm{N} 2-\mathrm{H} 2 \mathrm{~B} \cdots \mathrm{O} 1$ & $0.90(3)$ & $1.97(3)$ & $2.869(3)$ & 171(3) & $-\mathrm{x}+2,-\mathrm{y}+1,-\mathrm{z}+1$ \\
\hline $\mathrm{O} 3-\mathrm{H} 3 \cdots \mathrm{O} 1$ & $0.820(1)$ & $1.830(2)$ & $2.548(2)$ & $145.4(1)$ & - \\
\hline $\mathrm{O} 4-\mathrm{H} 4 \mathrm{~A} \cdots \mathrm{O} 2$ & $0.820(2)$ & $1.839(1)$ & $2.653(2)$ & 171.7(1) & $-\mathrm{x}+1, \mathrm{y}+1 / 2,-\mathrm{z}+1 / 2$ \\
\hline \multicolumn{6}{|c|}{$\mathbf{1 b}$} \\
\hline $\mathrm{N} 1-\mathrm{H} 1 \cdots \mathrm{O} 1$ & $0.861(2)$ & $1.819(2)$ & $2.678(3)$ & $176.2(1)$ & $-\mathrm{x},-\mathrm{y}+1,-\mathrm{z}+1$ \\
\hline $\mathrm{N} 2-\mathrm{H} 2 \mathrm{~A} \cdots \mathrm{O} 2$ & $0.860(3)$ & $1.940(2)$ & $2.780(3)$ & $165.0(2)$ & $-\mathrm{x},-\mathrm{y}+1,-\mathrm{z}+1$ \\
\hline $\mathrm{N} 2-\mathrm{H} 2 \mathrm{~B} \cdots \mathrm{O} 1$ & $0.860(2)$ & $1.906(2)$ & $2.764(3)$ & $176.0(2)$ & $-\mathrm{x}, \mathrm{y}+1 / 2,-\mathrm{z}+1 / 2$ \\
\hline $\mathrm{O} 3-\mathrm{H} 3 \mathrm{~A} \cdots \mathrm{O} 2$ & $0.820(2)$ & $1.761(1)$ & $2.492(2)$ & $147.5(1)$ & - \\
\hline $\mathrm{O} 4-\mathrm{H} 4 \cdots \mathrm{O} 3$ & $0.91(3)$ & $1.86(3)$ & $2.769(2)$ & 173(3) & $\mathrm{x},-\mathrm{y}+3 / 2, \mathrm{z}-1 / 2$ \\
\hline \multicolumn{6}{|c|}{ 1c } \\
\hline $\mathrm{N} 1-\mathrm{H} 1 \cdots \mathrm{O} 2$ & $0.860(2)$ & $1.858(2)$ & $2.703(2)$ & $166.7(1)$ & $-\mathrm{x}+1,-\mathrm{y}+1,-\mathrm{z}+1$ \\
\hline N2-H2A $\cdots \mathrm{O} 1$ & $0.860(2)$ & $1.919(2)$ & $2.771(3)$ & $170.5(1)$ & $-\mathrm{x}+1,-\mathrm{y}+1,-\mathrm{z}+1$ \\
\hline N2-H2B ‥ O1 & $0.861(2)$ & $1.975(1)$ & $2.767(2)$ & $152.5(1)$ & $y-1 / 4,-x+3 / 4, z-1 / 4$ \\
\hline $\mathrm{O} 3-\mathrm{H} 3 \mathrm{~A} \cdots \mathrm{O} 2$ & $0.820(2)$ & $1.795(1)$ & $2.522(2)$ & $146.9(1)$ & - \\
\hline $\mathrm{O} 4-\mathrm{H} 4 \mathrm{~A} \cdots \mathrm{O} 3$ & $0.83(3)$ & $1.94(3)$ & $2.770(2)$ & $173(3)$ & $-y+3 / 4, x+1 / 4, z+1 / 4$ \\
\hline \multicolumn{6}{|c|}{ 1d } \\
\hline $\mathrm{N} 1-\mathrm{H} 1 \cdots \mathrm{O} 2$ & $0.860(2)$ & $1.783(2)$ & $2.641(2)$ & $174.5(1)$ & $\mathrm{x},-\mathrm{y}+2, \mathrm{z}+1 / 2$ \\
\hline N2-H2A $\cdots \mathrm{O} 1$ & $0.860(2)$ & $1.996(2)$ & $2.844(3)$ & $168.8(2)$ & $\mathrm{x},-\mathrm{y}+2, \mathrm{z}+1 / 2$ \\
\hline N2-H2B . . O4 & $0.861(2)$ & $2.156(2)$ & $2.858(3)$ & $138.4(2)$ & $-\mathrm{x}+1,-\mathrm{y}+1,-\mathrm{z}+1$ \\
\hline $\mathrm{O} 3-\mathrm{H} 3 \mathrm{~A} \cdots \mathrm{O} 2$ & $0.84(3)$ & $1.79(3)$ & $2.540(3)$ & $148(3)$ & - \\
\hline O4-H4A $\cdots$ O1 & $0.94(3)$ & $1.63(3)$ & $2.500(3)$ & 151(3) & - \\
\hline \multicolumn{6}{|c|}{ 1e } \\
\hline $\mathrm{N} 3-\mathrm{H} 3 \ldots \mathrm{O} 2$ & $0.82(3)$ & $2.01(3)$ & $2.816(3)$ & $168(2)$ & $\mathrm{x}-1, \mathrm{y}, \mathrm{z}$ \\
\hline N4-H4A $\cdots$ O6 & $0.860(2)$ & $2.594(2)$ & $3.080(3)$ & $116.9(1)$ & $-\mathrm{x},-\mathrm{y}+2,-\mathrm{z}+1$ \\
\hline N4-H4A $\cdots \mathrm{O} 1$ & $0.860(2)$ & $1.973(2)$ & $2.778(3)$ & $155.4(1)$ & $\mathrm{x}-1, \mathrm{y}, \mathrm{z}$ \\
\hline N4-H4B $\cdots \mathrm{O} 2$ & $0.860(2)$ & $2.034(1)$ & $2.876(2)$ & 166.1(1) & $x-1,-y+3 / 2, z-1 / 2$ \\
\hline \multicolumn{6}{|l|}{ |1f } \\
\hline $\mathrm{N} 2-\mathrm{H} 2 \mathrm{~A} \ldots \mathrm{O} 2$ & $0.86(1)$ & $1.95(2)$ & $2.783(2)$ & $165(2)$ & $-\mathrm{x}+1 / 2, \mathrm{y}-1 / 2,-\mathrm{z}+1 / 2$ \\
\hline N1-H1A...O1 & $0.91(2)$ & $1.76(2)$ & $2.662(2)$ & $175(2)$ & $\mathrm{x}, \mathrm{y}-1, \mathrm{z}$ \\
\hline N2-H2B...O2 & $0.89(2)$ & $1.86(2)$ & $2.744(2)$ & $172(2)$ & $\mathrm{x}, \mathrm{y}-1, \mathrm{z}$ \\
\hline
\end{tabular}


as it was found to be omnipresent in all the reported salts (tables 3 and 4).

\subsection{Role of non-conventional hydrogen bond}

In general, the azole ' $\mathrm{N}$ ' decreases the electron density on the adjacent $\mathrm{C}-\mathrm{H}$ and thus provokes the hydrogen bond donating ability of $\mathrm{C}-\mathrm{H}$ protons. $\mathrm{C}-\mathrm{H} \cdots \mathrm{O}$ interaction was observed in the four salts. Since the $\mathrm{C}-\mathrm{H} \cdots \mathrm{O}$ bond was not linear, the $\mathrm{H} \cdots \mathrm{O}$ bond length was taken into consideration. The bond lengths were found to be 2.652(1) $\AA, 2.445(2) \AA, 2.493(2) \AA$ and 2.699(2) $\AA$ for salts 1b, 1c, 1d and 1e respectively. However, auxiliary hydrogen bond $(\mathrm{C}-\mathrm{H} \cdots \mathrm{O})$ was not observed in salts 1a and 1f. The weak $\mathrm{C}-\mathrm{H} \cdots \mathrm{O}$ interaction was observed for carbon C5 (carbon adjacent to $\mathrm{S}$ ) in $\mathbf{1 b}$ and $\mathbf{1 c}$ whereas carbon $\mathrm{C} 4$ (carbon adjacent to $\mathrm{N}$ ) was involved in $\mathrm{C}-\mathrm{H} \cdots \mathrm{O}$ interaction in 1d and 1e. This was due to the fact that 2,4- and 2,5dihydroxybenzoic acids ( $K_{\mathrm{a}} 3.22$ and 2.95$)$ in salts $\mathbf{1 b}$ and 1c were relatively weakly acidic. Thus it rendered acidity to thiazole protons to a lesser extent and hence the $\mathrm{C}-\mathrm{H} \cdots \mathrm{O}$ interaction was facilitated by involving $\mathrm{C} 5$ atom (adjacent to $\mathrm{S}$ atom). On the contrary, in the salts $1 \mathbf{d}$ and 1e, the coformers 2,6-dihydroxybenzoic acid ( $\left.\mathrm{p} K_{\mathrm{a}} 1.22\right)$ and 2,4-dinitrobenzoic acid $\left(\mathrm{p} K_{\mathrm{a}} 1.43\right)$ were relatively more acidic and thus enabled the $\mathrm{C} 4$ (carbon adjacent to $\mathrm{N}$ ) to involve in the $\mathrm{C}-\mathrm{H} \cdots \mathrm{O}$ interaction. Ideally, the $\mathrm{C}$ atom adjacent to the ring $\mathrm{N}$ would be acidic to participate in hydrogen bond formation. This convention was followed by $\mathbf{1 d}$, and $\mathbf{1 e}$, which was evident by their acidities. However, this was contradictory for salts $\mathbf{1 b}$ and 1c. Similar trend was supported by $\mathrm{C}-\mathrm{H} \cdots \mathrm{O}$ bond lengths, $\mathbf{1 b}$ having relatively more bond length had basket weave network, 1c layered arrangement and 1d more compact herring bone arrangement. The acidity of 2,4-dinitrobenzoic acid is more than 2,4-dihydroxybenzoic acid. Surprisingly the bond length for $\mathrm{H}$ (azole) ... O (nitro) interaction was 2.699(2) $\AA$ for 1e slightly higher than that for 1b 2.652(1) $\AA$. This could be due to distortion of the molecule (coformer) due to the presence of bulky nitro groups.

\section{Conclusion}

A series of six salts of 2-aminothiazole with different carboxylic acid coformers were synthesized and characterized by FT-IR, DSC, XRPD, ${ }^{1} \mathrm{H}$ NMR. The structures of all the reported salts were determined by the single crystal XRD. The SCXRD studies indicated that in all the reported salts, the API interacts with coformers via two point supramolecular synthon $\mathrm{N}-\mathrm{H} \cdots \mathrm{O}^{-}$and
$\mathrm{N}^{+}-\mathrm{H} \cdots \mathrm{O}^{-}$irrespective of the position/type of the substituents present on the coformers. The $\Delta \mathrm{r}$ varied in a linear manner with $\mathrm{N}^{+}-\mathrm{H} \cdots \mathrm{O}^{-}$distance in all the six salts. The $\mathrm{C}-\mathrm{H} \cdots \mathrm{O}$ bond distance was compliant with the acidity of the dihydroxy benozic acids and dinitrobenzoic acid. The auxiliary $\mathrm{C}-\mathrm{H} \cdots \mathrm{O}$ interactions played a critical role in the formation of supramolecular architectures.

\section{Supplementary Information}

IR spectral data of the salts; ${ }^{1} \mathrm{H}$ NMR spectra of the salts; DSC of the salts;XRPD of the bulk salt samples. Crystallographic information files (CIF's) have been deposited at the Cambridge Crystallographic Data Centre; CCDC Nos. 919166 for 1a, 919167 for 1b, 919168 for 1c, 919169 for 1d, 919171 for 1e, 924125 for 1f. This material is available free of charge via internet at http://www.ccdc.cam.ac.uk or E-mail: deposit@ccdc.cam.ac.uk.

\section{Acknowledgements}

D R T and M O would like to acknowledge the Director and HOD (Chemistry Department), NITK Surathkal for providing the research infrastructure. M O is grateful to NITK Surathkal for the fellowship. D R T and M $\mathrm{O}$ are also thankful to the Metallurgy Department for the PXRD facility. D R T and M O are indebted to the CSMCRI for extending NMR facility.

\section{References}

1. Huang K, Britton D, Etter M C and Byrn S R 1997 J. Mater. Chem. 7713

2. (a) Gao X, Friscic T and MacGillivray L R 2004 Ange. Chem. Int. Ed. 43 232; (b) Xiao J, Yang M, Laugher J W and Fowler F W 2000 Angew. Chem. Int. Ed. 392132

3. (a) Ma B Q, Zhang M and Coppens P 2002 Cryst. Growth Des. 2 7; (b) MacGillivray L R, Diamente P R, Reid J L and Ripmeester J A 2001 Chem. Commun. 1034; (c) MacGillivray L R, Diamente P R, Reid J L, Ripmeester J A 2000 Chem. Commun. 359

4. Taylor L D and Warner J C Process and composition for use in photographic materials containing hydroquinones. U.S. patent 5338644 A August 16, 1994. Cont. of U.S. 5, 177, 262

5. Dastidar P 2008 Chem. Soc. Rev. 372699

6. Desiraju G R 1995 Angew. Chem. Int. Ed. Engl. 342311

7. Brody T 1999 In Nutritional Biochemistry ( $2^{\text {nd }}$ ed.) (San Diego: Academic Press)

8. Martin P R, Singleton C K and Hiller-Sturmhofel S 2003 Alcohol Research and Health 27134

9. Metzger J V In Thiazole and its Derivatives (II) 1979 (New York: John Wiley \& Sons) 
10. Décor A, Grand-Maître C, Hucke O, O’Meara J, Kuhn C, Constantineau-Forget L, Brochu C, Malenfant E, Bertrand-Laperle M, Bordeleau J, Ghiro E, Pesant M, Fazal, G, Gorys V, Little M, Boucher C, Bordeleau S, Turcotte P, Guo T, Garneau M, Spickler C and Gauthier A 2013 Bioorg. Med. Chem. Lett. 133481

11. Yadapalli R K, Chourastra O P, Jogi, M P, Podile A R and Perali R S 2013 Med. Chem. Res. 222785

12. Samadhiya P, Sharma R, Srivastava S K and Srivastava S D 2012 J. Serb. Chem. Soc. 775995

13. Li M, Sim Y and Ham S W 2010 Bull. Korean Chem. Soc. 311463

14. Nardelli M, Pellizi G, Vitali F, Bordi, F, Plazzi, P V and Vitali T 1987 Acta Crystallogr. C $\mathbf{4 3} 507$

15. Jin S, Yan P, Wang D, Xu, Y, Jiang, Y, Hu L 2012 J. Mol. Struc. 101655

16. Lynch D E, Smith G, Byriel K A and Kenard C H L 1998 Aust. J. Chem. 51587

17. Kuz'mina L G and Struchkov Y T 1984 Zh. Struckt. Khim 2588

18. Mohamed H A, EI-Medani S M and Ramadan R M 2005 J. Indian Chem. Soc. 82799

19. Lynch D E, Nicholis L J, Smith G, Byriel K A and Kennard C H L Acta Cryst. B $\mathbf{5 5} 758$

20. Kelleher J M, Lawrence S E, Moynihan H A 2006 Cryst. Eng. Comm. 6327

21. Cheney M L, Weyna D R, Shan N, Hanna M, Wojtas L and Zaworotko M 2010 Cryst. Growth Des. 104401

22. (a) Childs S L, Chyall L J, Dunlap J T, Smolenskaya, V N, Stahly B C and Stahly G P 2004 J. Am. Chem. Soc. 56 241; (b) Tao Q, Chen J, Ma L and Lu T 2012 Cryst. Growth Des. 12 3144; (c) Nishiguchi N, Kinuta T, Sato T, Nakano Y, Harada T, Tajima N, Fujiki M, Kuroda R, Matsubara Y and Imai Y 2012 Cryst. Growth Des. 12 1859; (d) Okuno T, Sakoda Y, Kinuta T, Sato T, Tokutome H, Tajima N, Nakano Y, Fujiki M, Kuroda R and Imai Y 2012 Cryst. Eng. Comm. 14 4819; (e) Smith G, Wermuth U D and Healy P C 2006 Acta Crystallogr. Sect. E: Struct. Rep. Online 62 o1863; (f) Imai Y, Murata K, Asano N, Nakano Y, Kawaguchi K, Harada T, Sato T, Fujiki M, Kuroda R and Matsubara Y 2008 Cryst. Growth Des. 8 3376; (g) Lemmerer A 2011 Cryst. Growth Des. 11 583; (h) Ivanova B and Spiteller M 2011 Spectrochim. Acta Part A 77 849; (i) Chen S, Patrick B O, Scheffer J R 2004 J. Org. Chem. 692711 ; (j) Smith G and Wermuth U D 2011 Acta Crystallogr. Sect. E: Struct. Rep. Online 67 O2461; (k) Tani T, Sada K,
Ayabe M, Iwashita Y, Kishida T, Shirakawa M, Fujita N and Shinkai S 2004 Collect. Czech. Chem. Commun. 69 1292; (1) Nishiguchi N, Kinuta T, Sato T, Nakano Y, Tokutome H, Tajima N, Fujiki M, Kuroda R, Matsubara Y and Imai Y 2012 Chem. Asian J. 7 360; (m) Lemmerer A 2012 J. Chem. Cryst. 42 498; (n) Lemmerer A 2011 Acta Cryst. Sect. C: Cryst. Struct. Commun. 67 o92; (o) Koshima H, Nagano M and Asahi T 2005 J. Am. Chem. Soc. 127 2455; (p) Das U K, Trivedi D R, Adarsh N N and Dastidar P 2009 J. Org. Chem. 747111

23. (a) Ji B, Deng D, Ma N, Miao S, Ji L, Liu P and Li X 2011 Cryst. Growth Des. 11 4090; (b) Li J, Tao Y, Yu Q and Bu X 2006 Cryst. Growth Des. 11 2493; (c) Mac Donald J C, Dorrestein P C and Pilley M M 2001 Cryst. Growth Des. 1 29; (d) Aakeroy, C B, Desper J, Leonard B and Urbina J F 2005 Cryst. Growth Des. 5 865; (e) Lemmerer A, Bourne S A and Fernendes M A 2008 Cryst. Growth Des. 81106

24. (a) Ermer O and Eling A 1994 J. Chem. Soc. Perkin Trans. 2 925; (b) Hannesian S, Simard M and Roelens S 1995 J. Am. Chem. Soc. 117 7360; (c) Allen F H, Hoy V J, Howard J A K, Thalladi V R, Desiraju G R, Wilson C C and McIntyre G J 1997 J. Am. Chem. Soc. 119 3477; (d) Vangala V R Bhogala B R, Dey A, Desiraju G R, Broder C K, Smith P S, Mondal R, Howard, J A K Wilson C C 2003 J. Am. Chem. Soc. 14495; (e) Hannesian S, Saladino R, Margarita R and Simard M 1999 Chem. Eur. J. 5 2169; (f) Dey A, Desiraju G R, Mondal R and Howard J A K 2004 Chem. Commun. 2528

25. (a) Aakeroy C B and Salmon D J 2005 Cryst EngComm. 7 439; (b) Grossel C M, Dwyer A N, Hursthouse M B and Orton J B 2006 Cryst. Eng. Commun. 8 123; (c) Varughese S and Pedireddi V R 2006 Chem. Eur. J. 12 1597; (d) Du M, Zhang Z H, Zhao X J, Cai H 2006 Cryst. Growth Des. 6 114; (e) Bond A D 2003 Chem Commun. 250; (f) Bhogala B R and Nangia A 2008 New J. Chem. 32 800; (g) Sarma B, Nath, N K, Bhogala B and Nangia A 2009 Cryst. Growth Des. 9 1546; (h) Bis, J A and Zaworotko M J 2005 Cryst. Growth Des. 51169

26. Oxford Diffraction, CrysAlis PRO, Oxford Diffraction Ltd., Yarnton, England 2009

27. Bruker SMART V5.630, SAINT-PLUS V6.45 and SADABS Bruker Analytical X-ray Systems Inc., Madison, Wisconsin, USA, 2003

28. Sheldrick G M 2008 Acta Crystallogr. A 64112 